\title{
Desain Kapal Pesiar dengan Hydraulic Platform untuk Pariwisata di Pantai Nongsa, Batam
}

\author{
Karina Dayusari, Ardi Nugroho Yulianto, dan Hesty Anita Kurniawati \\ Departemen Teknik Perkapalan, Fakultas Teknologi Kelautan, Institut Teknologi Sepuluh Nopember (ITS) \\ e-mail: tita@na.its.ac.id
}

\begin{abstract}
Abstrak-Kota Batam secara geografis mempunyai letak yang sangat strategis, yaitu di jalur pelayaran dunia internasional.Pantai Nongsa memiliki potensi yang sangat besar aktual untuk memberi kontribusi terhadap kemajuan ekonomi Kota Batam maupun daerah sekitarnya. Pantai Nongsa dan Kampung Tua berada di kawasan Nongsa, Pulau Batam. Nongsa adalah daerah di sebelah utara Batam. Untuk lebih menarik minat pengunjung maka diperlukan inovasi yang belum ada di Nongsa, yaitu Kirei Cruise. Adalah kapal wisata yang menawarkan fasilitas berupa platform hidrolik yang dijadikan tambahan sebagai tempat untuk bersantai menikmati pemandangan laut dari jarak yang lebih dekat. Ukuran utama yang didapat berdasarkan kapal yang nantinya membawa penumpang ke Kirei Cruise ini dari serangkaian proses desain yang sudah dilakukan, maka didapatkan LOA = $58 \mathrm{~m}, \mathrm{~B}=12 \mathrm{~m}, \mathrm{H}=9 \mathrm{~m}, \mathrm{~T}=4,5 \mathrm{~m}$ dengan jumlah penumpang sebanyak 24 orang dan 22 crew. Setelah di dapatkan ukuran utama ini, dilanjutkan dengan pembuatan Lines Plan, General Arrangement dan desain 3D.
\end{abstract}

Kata Kunci-Pulau Batam, Pulau Nongsa, Kapal Wisata, Platform Hidrolik.

\section{PENDAHULUAN}

$\mathrm{K}$ OTA Batam adalah sebuah kota terbesar di Provinsi Kepulauan Riau, Indonesia. Pulau Batam berada di kawasan Selat Singapura dan Selat Malaka yang berbatasan langsung dengan bagian utara yaitu Selat Singapura, bagian selatan yaitu Kecamatan Senayang, bagian barat yaitu Kecamatan Karimun, dan bagian timur yaitu Kecamatan Bintan Utara. Kota Batam secara geografis mempunyai letak yang sangat strategis, yaitu di jalur pelayaran dunia internasional. Kota Batam berdasarkan Peraturan Daerah Nomor 2 Tahun 2004 tentang Rencana Tata Ruang Wilayah Kota Batam Tahun 2004-2014, terletak antara: - 0o25' 29" LU -1o15'00" LU - 103o34' 35" BT -104o26'04"BT. Hal ini juga didukung dengan mudahnya akses menuju pulau ini. Pulau Batam banyak dikunjungi oleh wisatawan lokal maupun mancanegara setiap tahunnya sehingga menjadi salah satu peluang untuk pariwisata di Pulau Batam, salah satunya di tepi laut Pantai Nongsa.

Kota Batam memiliki potensi maupun kemampuan aktual untuk memberi kontribusi terhadap kemajuan ekonomi Nasional maupun daerah sekitarnya. Posisinya yang sangat dekat dengan negara industri baru Singapura, membuat kawasan ini sangat berpotensi untuk menampung luapan ekonomi dari negara pulau yang sudah tergolong maju tersebut. Nilai ekonomis kawasan ini sudah tak terbantahkan sejak dikembangkan secara terencana oleh pemerintah. Sampai dengan Desember 2013, nilai ekspor nonmigas Batam adalah US \$ 9.36 juta serta Penanaman Modal Asing (PMA) sebanyak US \$ 7.28 miliar (Pemerintah Kota Batam, 2018).

Perpres No 105 Tahun 2015 yang dikeluarkan Presiden Jokowi ini diberlakukan untuk mempermudah kapal pesiar dan yatch asing yang membawa wisatawan mancanegara untuk masuk ke wilayah perairan Indonesia. Ini untuk meningkatkan jumlah wisatawan mancanegara masuk ke Indonesia yang tentunya akan menambah devisa bagi Indonesia. Pemerintah Kepulauan Riau menargetkan 2,5 juta kunjungan pelancong asing di tahun 2016 namun masih perlu dilakukan peningkatan fasilitas penunjang dan inovasi baru. Inovasi yang ingin ditingkatkan yaitu pada sektor wisata laut yang menarik wisatawan cukup banyak dari dalam dan luar negeri [1]. Berkaca pada fakta tersebut maka pada penelitian Jurnal dilakukan desain sebuah kapal pesiar sebagai penunjang pariwisata di sekitar Pantai Nongsa dengan fasilitas hydraulic platform sehingga berfungsi untuk melihat keindahan pantai.

\section{TINJAUAN PUSTAKA}

\section{A. Point Based Design}

Metode tersebut dilakukan dengan cara mencari atau merencanakan satu ukuran utama yang sesuai dengan owner requirement. Selanjutnya dari ukuran utama tersebut dilakukan pemeriksaan apakah memenuhi persyaratan dan ketentuan atau tidak. Apabila tidak memenuhi persyaratan dan ketentuan maka pada ukuran utama tersebut dilakukan perubahan atau koreksi hingga memenuhi persyaratan dan ketentuan yang ada. Dalam proses ini tidak dilakukan optimasi [2].

\section{B. Kapal Pesiar}

Kapal pesiar (cruise liner atau cruise ship) adalah kapal penumpang yang dipakai untuk peyanan pesiar. Penumpang menaiki kapal pesiar untuk menikmati waktu yang dihabiskan diatas kapal yang dilengkapi fasilitas penginapan dan perlengkapan bagaikan hotel berbintang. Sebagian kapal pesiar memiliki rute pelayaran yang selalu kembali ke pelabuhan asal keberangkatan. Lama pelayaran pesiar d lbisa berbeda-beda mulai dari beberapa hari sampai sekitar 3 bulan [3].

\section{Sistem Hidrolik}

Tekanan oli yang besar diperlukan untuk mendapatkan tenaga yang cukup besar untuk membuat sistem hidrolik dapat bekerja secara maksimal. Berdasarkan dua faktor inilah, sistem hidrolik bekerja menggunakan dua sistem kerja yakni Sistem Terbuka dan Tertutup. Pada sistem hidrolik terbuka ini, jika katup pengontrol yang digunakan berada dalam keadaan yang netral menyebabkan aliran minyak hidrolik yang merupakan hasil dari pompa akan dialirkan langsung menuju tangki hidrolik yang terhubung langsung dengan udara luar. Namun pada sistem tertutup akan dialirkan menuju sistem tertutup yang tidak terhubung dengan udara luar akan membuat tekanan antara pompa dan juga katup naik sampai batasan tertentu untuk membuat pompa berhenti mengalirkan minyak hidrolik menuju sistem hidrolik. 


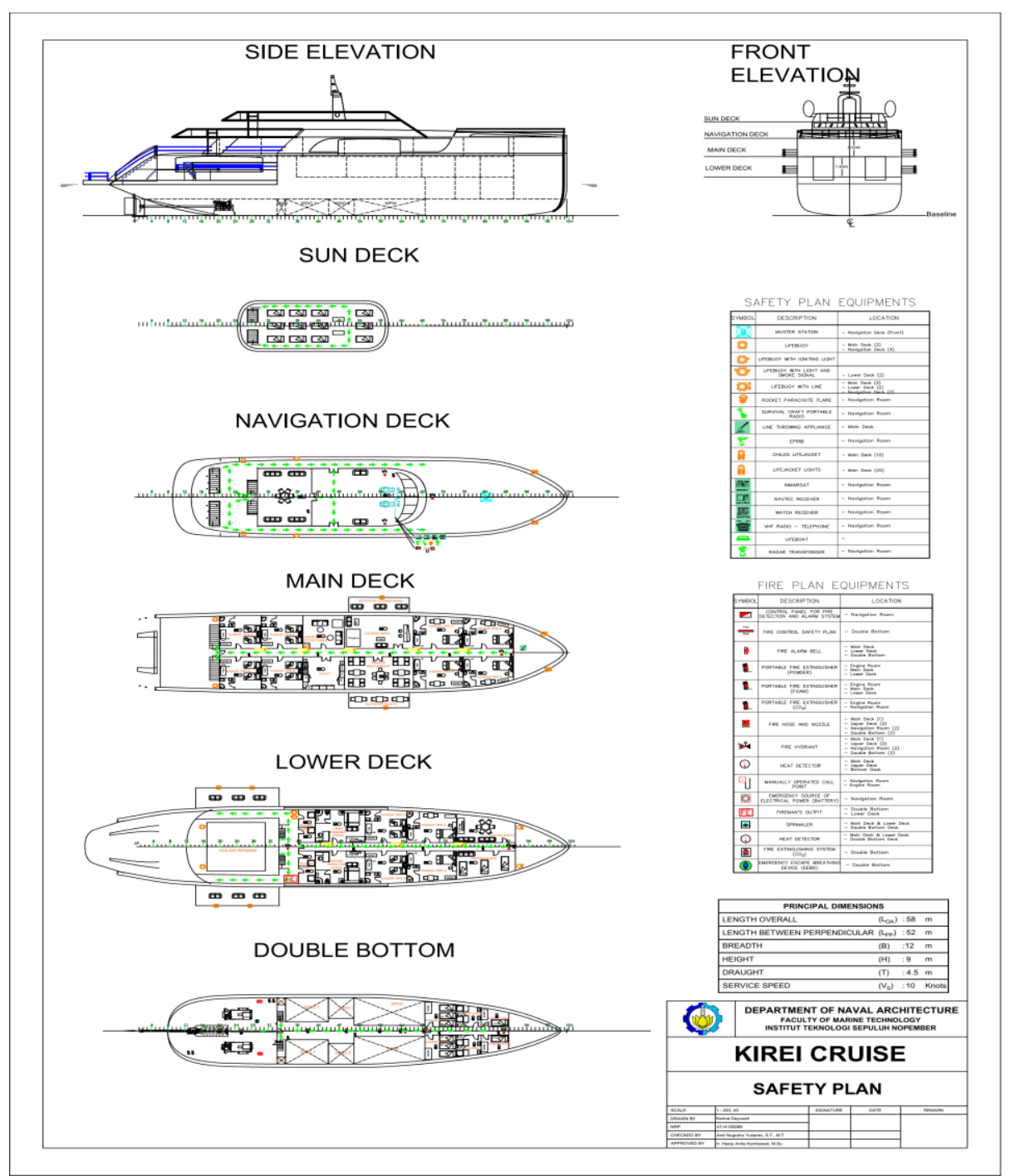

Gambar 1. Desain Safety Plan.

Gambar 2. Peta Pulau Batam.

\section{Safety Plan}

Desain safety plan terdiri dari life saving appliances dan fire control equipment. Life saving appliances adalah standar keselamatan yang harus dipenuhi oleh suatu kapal, untuk menjamin keselamatan awak kapal dan penumpang

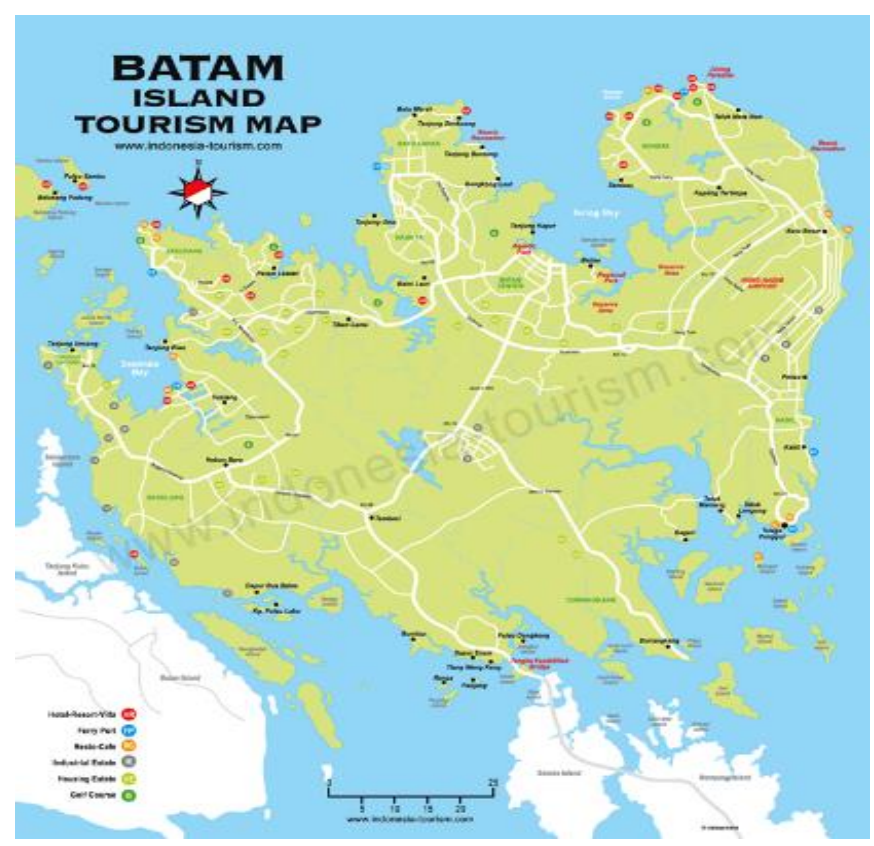

ketika terjadi bahaya. Fire control equipment adalah standar sistem pemadam kebakaran yang harus ada pada kapal. Regulasi life saving appliances mengacu pada LSA code, sedangkan fire control equipment mengacu pada FSS code. Hasil desain safety plan dapat dilihat pada Gambar 1. 


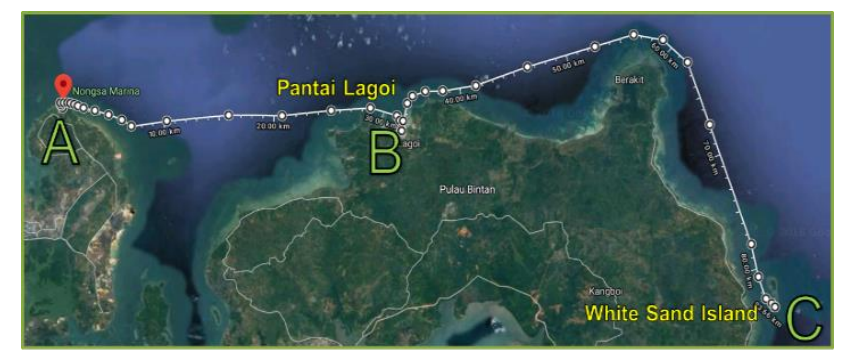

Gambar 3. Alur Wisata Perjalanan.

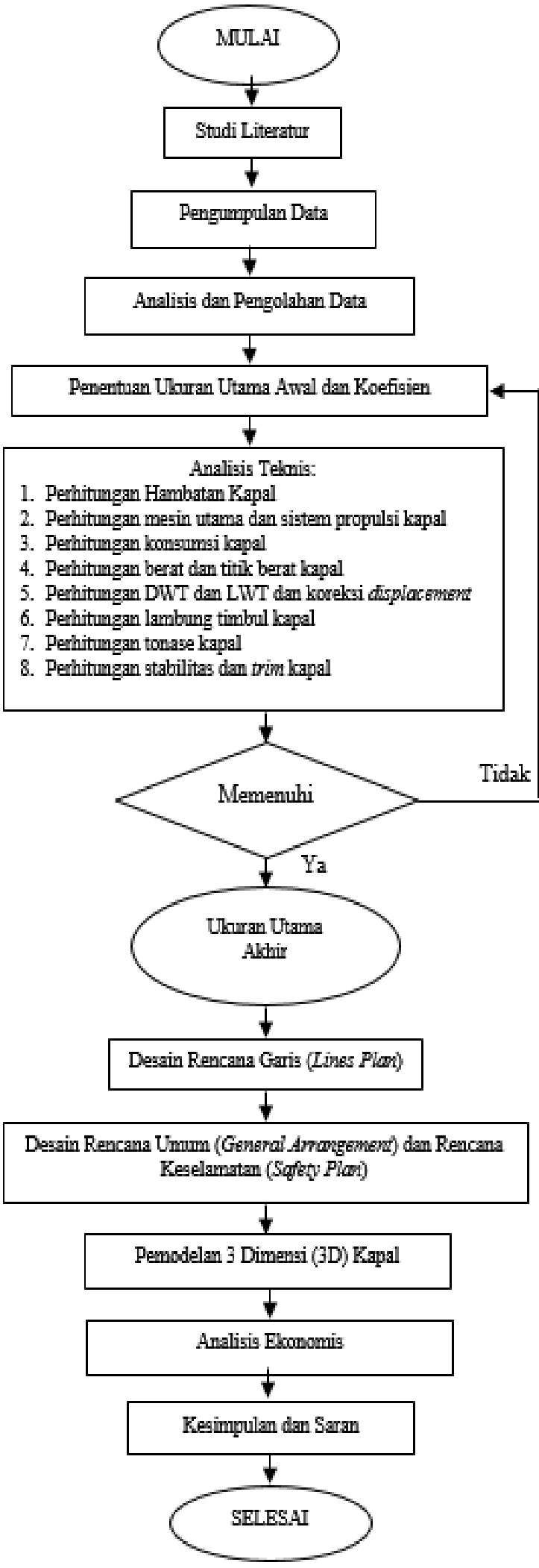

Gambar 4. Bagan Alir Pengerjaan Jurnal.

\section{METODOLOGI}

\section{A. Pengumpulan Data}

Dalam pengerjaan Jurnal ini dilakukan pengambilan data. Data yang digunakan merupakan data sekunder yaitu data yang didapatkan tidak secara pengukuran langsung di lapangan, melainkan dari website penyedia jasa pariwisata di Pulau Nongsa.

\section{B. Pengolahan Data}

Setelah pengumpulan data, selanjutkan adalah melakukan perhitungan dan analisis. Perhitungan yang dibahas pada Jurnal ini adalah perhitungan teknis dan perhitungan ekonomis. Dan juga dilakukan analisis pada perhitungan ekonomis untuk mendapatkan berapa harga yang layak untuk dilakukan investasi dan untuk balik modal.

\section{ANALISIS TEKNIS}

\section{A. Penentuan Payload}

Jumlah kapasitas yang dapat ditampung oleh Hotel di sekitar Pulau Nongsa adalah sebanyak 500 orang dan dari referensi kapal existing, serta dari data kunjungan wisatawan di Pulau Nongsa bahwa tiap tahunnya pengunjung mengalami kenaikan. Rata-rata tiap tahunnya kedatangan pengunjung sebanyak 23ribu pengunjung dan jika diasumsikan $20 \%$ selama setahun sebanyak 4600 orang tiap tahunnya, maka diasumsikan bahwa $20 \%$ dari total penumpang selama satu tahun akan menaiki kapal ini atau sama dengan 4608 pengunjung yang akan menaiki kapal ini untuk kapasitas kapal 24 orang. Maka didapatkan jumlah penumpang kapal ini adalah 24 penumpang.

\section{B. Penentuan Lokasi}

Pulau Nongsa adalah pulau terluar Indonesia yang terletak di perbatasan Indonesia dengan Singapura, dan merupakan wilayah dari pemerintah kota Batam, provinsi Kepulauan Riau. Akses menuju Pulau Nongsa dapat ditempuh dari dua lokasi yaitu dari pelabuhan Sekupang atau dari Desa Nongsa Pantai dengan waktu tempuh kurang lebih selama 10 menit dengan menggunakan perahu motor. Peta dapat dilihat pada Gambar 2 dan 3.

\section{Penentuan Ukuran Utama}

Setelah ditentukannya kapasitas payload yang akan diangkut pada Kirei Cruise tersebut maka selanjutnya adalah dilakukannya penentuan ukuran utama kapal. Ukuran utama kapal didapatkan melalui proses metode point based design. (Tabel 1)

Tabel 1.

Ukuran Utama Kapal

\begin{tabular}{cc}
\hline \hline Nama & Ukuran \\
\hline Panjang Perpendicular (LPP) & 52 meter \\
Lebar (B) & 11.5 meter \\
Sarat (T) & 4.5 meter \\
Tinggi (H) & 9 meter \\
Vs & 10 nots \\
\hline \hline
\end{tabular}

\section{Pemilihan Tenaga Penggerak}

Perhitungan daya yang dibutuhkan kapal ini didapatkan sekitar $600 \mathrm{~kW}$. Mesin induk yang akan dipilih harus mempunyai kapasitas daya dorong yang harus bisa menghasilkan daya tersebut. Mesin yang dipilih adalah marine prupullsion dengan merk Yanmar yang mempunyai daya sebesar $749 \mathrm{~kW}$ dan berat $2418 \mathrm{~kg}$. Kemudian 


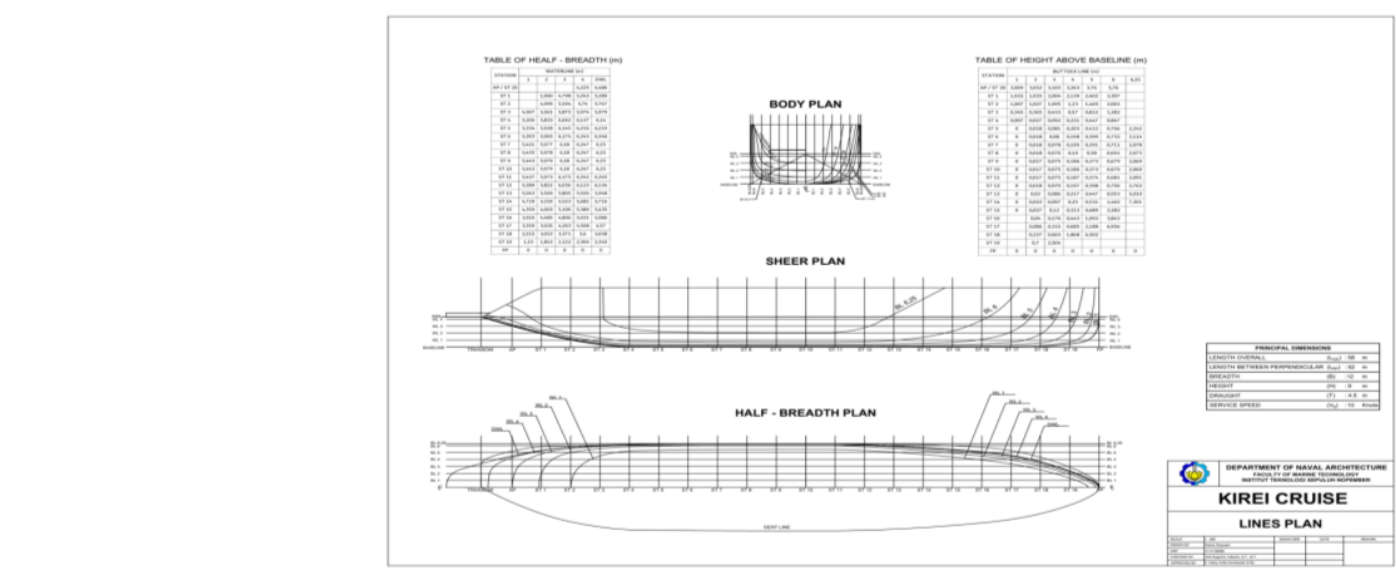

Gambar 5. Desain Rencana Garis.

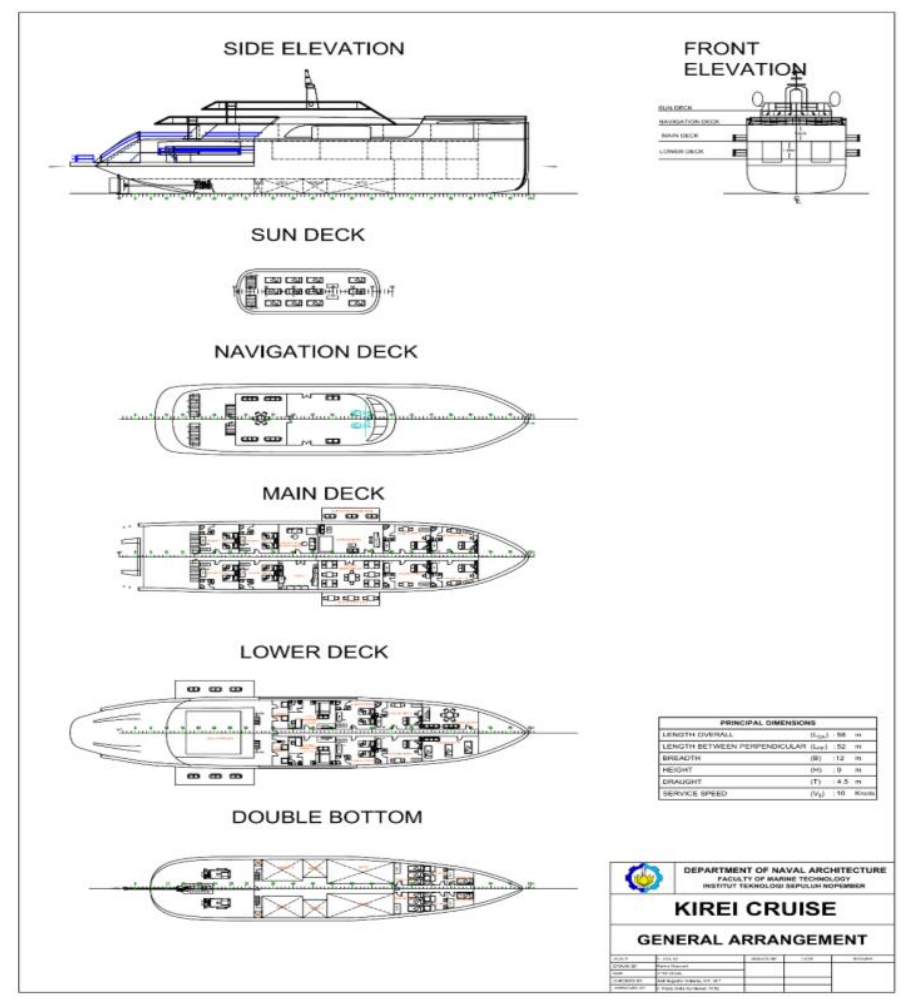

Gambar 6. Desain rencana umum.

dibutuhkan juga tenaga pendukung yaitu berupa genset dengan asumsi daya $25 \%$ dari daya mesin induk. Mesin tenaga pendukung yang dipilih yaitu genset dengan merk Caterpillar dengan daya $590 \mathrm{~kW}$ dan berat $3221 \mathrm{~kg}$. (Tabel 2)

Tabel 2.

Pemilihan Tenaga Gerak

\begin{tabular}{ccc}
\hline \hline Mesin & Tipe & Daya \\
\hline Mesin Induk & 6AYEM-GT & $749 \mathrm{~kW}$ \\
Mesin Bantu & C32 ACERT-GT & $590 \mathrm{~kW}$ \\
\hline \hline
\end{tabular}

\section{E. Diagram Alir}

Diagram alir dalam studi ini dapat dlihat pada Gambar 4.

\section{F. Perhitungan Berat Kapal}

Perhitungan berat kapal dibagi menjadi dua yaitu lightweight (LWT) dan deadweight (DWT). Lightweight merupakan berat kapal kosong tanpa muatan yang berarti hanya terdiri dari berat struktur kapal tersebut, berat instalasi permesinan, serta berat dari perlengkapan kapal itu sendiri. Deadweight merupakan berat dari muatan kapal yang akan dibawa selama perjalanan berlangsung yaitu terdiri dari payload, bahan bakar mesin, kebutuhan awak kapal, serta air bersih untuk perhitungan LWT kapal ini didapatkan sebesar 1583 ton dan perhitungan DWT kapal didapatkan sebesar 18.4 ton.

\section{G. Perhitungan Freeboard}

Freeboard merupakan selisih tinggi kapal antara yang tercelup di dalam air dan yang tidak. Perhitungan freeboard mengacu aturan dari International Maritime Organization dalam konvensi International Convention on Load Lines (ICLL). Hasil perhitungan didapatkan freeboard minimal dari kapal ini adalah 1,26 meter [4].

\section{H. Penentuan Load Case}

Pemakaian kapal ini dapat dibagi menjadi dua kasus atau yang biasa dinamakan load case. Load Case A yaitu keadaan dimana saat kapal membawa muatan consumables penuh (100\% Full Load). Load Case B adalah dimana saat kapal hanya membawa setengah muatan consumables (50\% Full Load). 


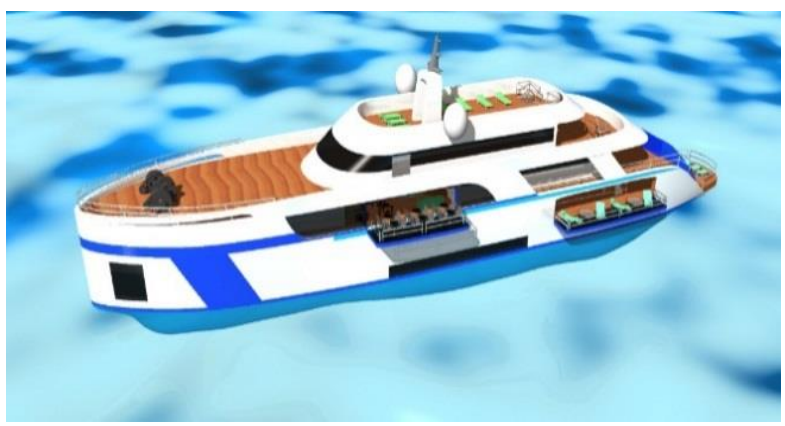

Gambar 7. Desain 3D Model Tampak Samping.

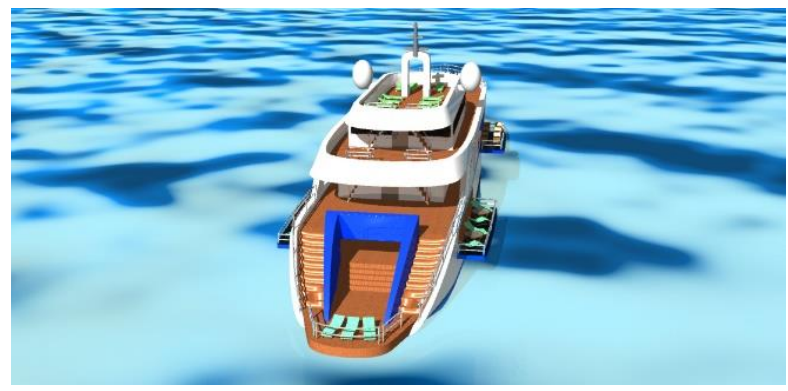

Gambar 8. Gambar 3D Model Tampak Belakang.

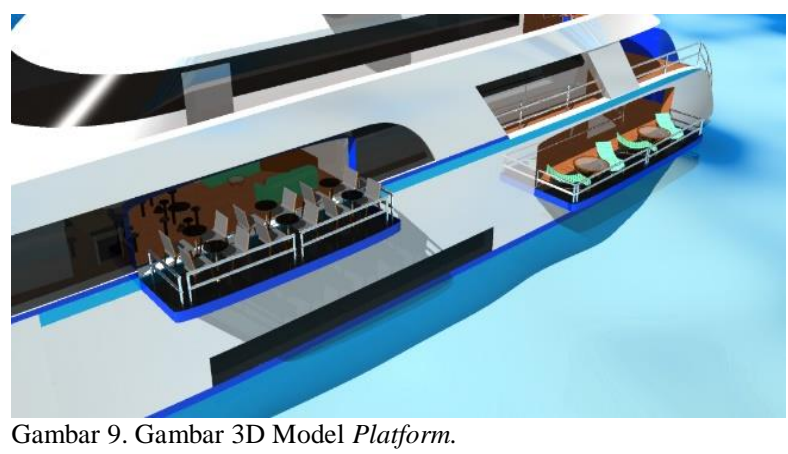

\section{Perhitungan Trim}

Trim adalah selisih antara sarat pada bagian depan dan bagian belakang sebuah kapal. Fenomena ini terjadi dikarenakan pembagian beban yang tidak merata di atas kapal untuk bagian depan maupun bagian belakang kapal. Aturan yang disyaratkan oleh IMO dalam Safety of Lives at Sea (SOLAS) adalah nilai trim tidak melebihi dari $0,5 \%$ panjang garis air kapal [4].

Untuk hasil dari perhitungan trim tiap-tiap load case dapat dilihat pada Tabel 3 .

Tabel 3.

Hasil Perhitungan Trim

\begin{tabular}{|c|c|c|c|}
\hline Load Case & Kriteria & $\begin{array}{c}\text { Hasil } \\
\text { (m.rad) }\end{array}$ & Ket \\
\hline $\begin{array}{c}\text { Load Case A (100\% } \\
\text { Full Load) }\end{array}$ & \multirow{2}{*}{$<0.26$} & 0.119 & Pass \\
\hline $\begin{array}{c}\text { Load Case B (50\% Full } \\
\text { Load) }\end{array}$ & & 0.246 & Pass \\
\hline
\end{tabular}

\section{J. Perhitungan Stabilitas}

Stabilitas kapal merupakan perhitungan bagaimana karakteristik keseimbangan kapal. Untuk kriteria stabilitas kapal juga diatur oleh IMO dalam Intact Stability Code (ISC). Perhitungan stabilitas juga dilakukan untuk tiap-tiap load case yang telah ditentukan. Kriteria yang dihitung ada lima yaitu, sudut maksimum pada sudut 30 derajat (I), sudut maksimum pada sudut 40 derajat (II), sudut maksimum pada sudut antara 30 dan 40 derajat (III), sudut maksium GZ (IV), jarak GMT (V), dan sudut equilibrium (VI) (Tabel 4). [5]

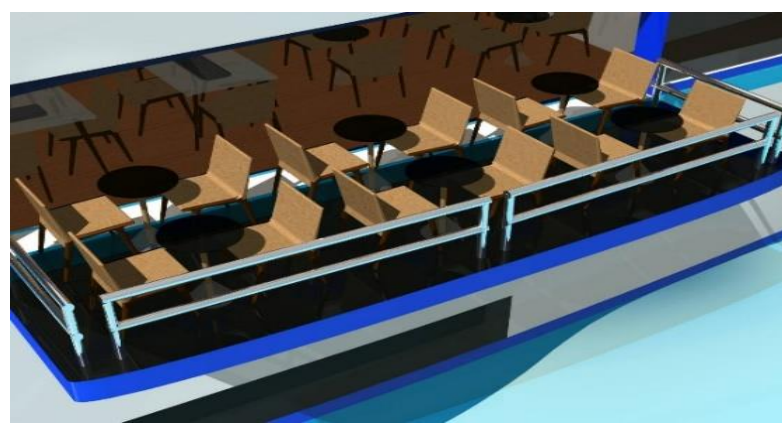

Gambar 10. Fasilitas Outdoor Restaurant.

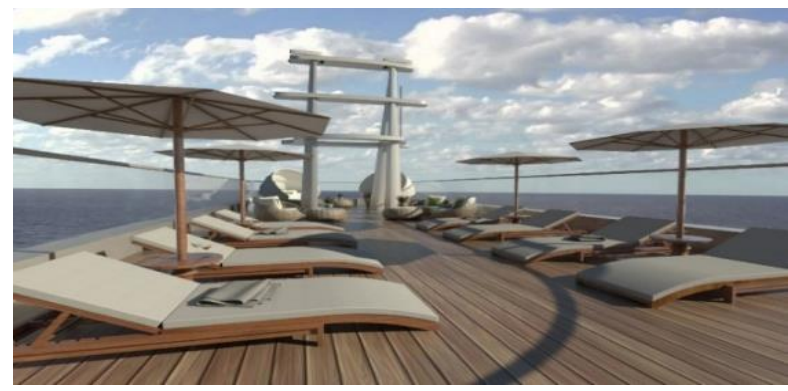

Gambar 11. Fasilitas Sun Deck.

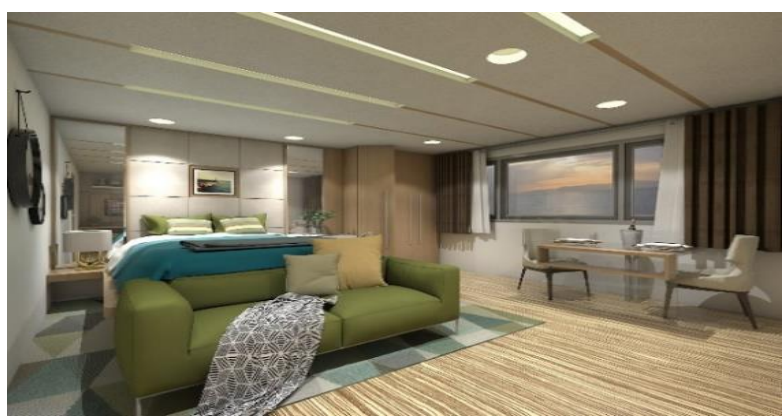

Gambar 12. Fasilitas Kamar.

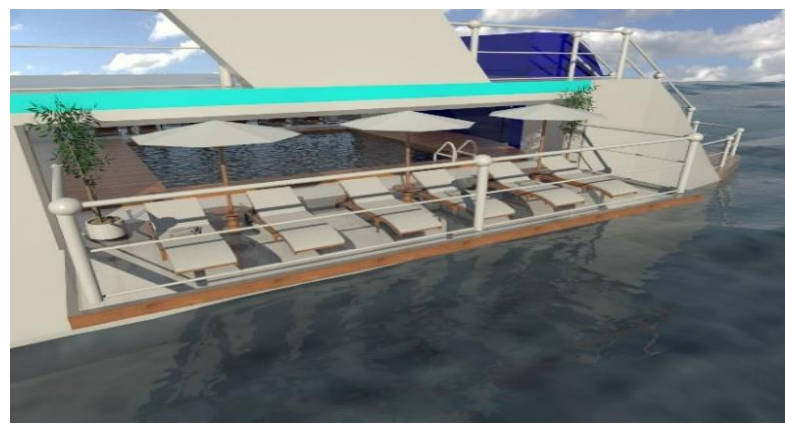

Gambar 13. Fasilitas Area Kolam Renang.

Tabel 4.

Hasil Perhitungan Stabilitas

\begin{tabular}{cccc}
\hline \hline \multirow{2}{*}{ Kriteria } & & \multicolumn{2}{c}{ Load Case } \\
\cline { 3 - 4 } & & A (m.rad) & B (m.rad) \\
\hline Area 0 to 30 & $\geq 3.1513$ & 5.4744 & 4.5045 \\
Area 0 to 40 & $\geq 5.1566$ & 9.9970 & 8.099 \\
Area 30 to 40 & $\geq 1.7189$ & 4.5227 & 3.5946 \\
Max GZ at 30 or & $\geq 0.200$ & 0.730 & 0.565 \\
Greater & & & 60 \\
Angle of & $\geq 25$ & 60 & \\
Maximum GZ & & & 0.515 \\
Initial GMt & $\geq 0.150$ & 0.629 & 4.5045 \\
\hline Area 0 to 30 & $\geq 3.1513$ & 5.4744 & Pass \\
\hline \hline
\end{tabular}

\section{K. Desain Rencana Garis}

Pembuatan model dilakukan dari pembentukan badan kapal sesuai dengan ukuran utama yang telah dihitung. Hasil rencana garis dapat dilihat pada Gambar 5. 


\section{Desain Rencana Umum}

Pembuatan rencana umum ini didasari dari kebutuhan tangki yang telah dihitung, kapasitas payload yang telah dihitung, serta ukuran utama yang telah didapat. Hasil rencana umum dapat dilihat pada Gambar 6.

\section{Desain 3D Model}

Desain model 3D dibuat merujuk dari gambar desain rencana umum. Desain gambar model 3D dapat dilihat pada Gambar 7-13.

Tabel 5.

Analisis Ekonomis

\begin{tabular}{|c|c|c|}
\hline \multirow[b]{2}{*}{ Komponen Ekonomis } & \multicolumn{2}{|c|}{ Nilai } \\
\hline & $\begin{array}{c}100 \% \\
\text { Penumpang }\end{array}$ & $75 \%$ Penumpang \\
\hline Fixed Cost & \multicolumn{2}{|c|}{ Rp. 840.342 .055} \\
\hline NPV & Rp. 13.058 .330 .180 & Rp. 224.509 .539 \\
\hline IRR & $42,628 \%$ & $15,5691 \%$ \\
\hline $\mathrm{PP}$ & $\begin{array}{c}3 \text { Tahun } 6 \text { Bulan } \\
\text { Off Peak }\end{array}$ & 6 Tahun 8 Bulan \\
\hline $\begin{array}{c}\text { Reguler } \\
\text { Weekdays }\end{array}$ & Rp. 1.013.274.182 & Rp 963.695.017,36 \\
\hline Reguler Weekend & Rp 949.753.679 & Rp919.813.983,30 \\
\hline VIP Weekdays & Rp 959.886.887 & Rp 926.921.537,09 \\
\hline VIP Weekend & $\begin{array}{c}\mathrm{Rp} 929.581 .919 \\
\text { Peak Season }\end{array}$ & Rp 905.541.007,69 \\
\hline $\begin{array}{c}\text { Reguler } \\
\text { Weekdays }\end{array}$ & Rp. 918.741 .314 & Rp. 897.801.340,96 \\
\hline Reguler Weekend & Rp. 880.935.566 & Rp. $870.423 .905,31$ \\
\hline VIP Weekdays & Rp. 896.145.263 & Rp. 881.511.001,37 \\
\hline VIP Weekend & Rp. 873.899 .808 & Rp. $865.261 .588,90$ \\
\hline
\end{tabular}

A. Pilihan Lokasi Wisata

Tabel 6.

Pilihan Lokasi Wisata

\begin{tabular}{|c|c|c|c|c|}
\hline Pilihan Hari & \multicolumn{4}{|c|}{ Tujuan Wisata } \\
\hline 1 Day Trip & $\begin{array}{c}\text { Nongsa Point } \\
\text { Marina }\end{array}$ & $\begin{array}{r}\text { Max' } \\
\mathrm{Ce}\end{array}$ & $\begin{array}{l}\text { Prive } \\
\text { re }\end{array}$ & $\begin{array}{c}\text { Nongsa Point } \\
\text { Marina }\end{array}$ \\
\hline $\begin{array}{c}2 \text { Days } 1 \text { Night } \\
\text { Trip }\end{array}$ & $\begin{array}{c}\text { Nongsa Point } \\
\text { Marina }\end{array}$ & $\begin{array}{l}\text { Max's } \\
\text { Drive } \\
\text { Centre }\end{array}$ & $\begin{array}{l}\text { White } \\
\text { Sand } \\
\text { Island }\end{array}$ & $\begin{array}{c}\text { Nongsa Point } \\
\text { Marina }\end{array}$ \\
\hline
\end{tabular}

Pilihan wisata di Kirei Cruise dibagi menjadi dua tipe, yaitu weekdays (1 Day Trip) dan weekends (2 Days 1 Night Trip). Perbedaan dalam dua trip tersebut dapat dilihat pada Tabel .

\section{KESIMPULAN}

\section{A. Kesimpulan}

Dari seluruh pembahasan yang sudah dipaparkan pada bab sebelumnya, maka kesimpulan dari Jurnal ini adalah sebagai berikut:

1. Berdasarkan hasil analisis penumpang maka didapatkan penumpang yang bisa diangkut sebanyak 24 penumpang dengan $22 \mathrm{crew}$.

2. Ukuran utama kapal yang didapat adalah:

$\begin{array}{ll}\text { Length Overal } & : 58 \text { meter } \\ \text { Breadth } & : 12 \text { meter } \\ \text { Draught } & : 4,5 \text { meter } \\ \text { Depth } & : 9 \text { meter } \\ \text { Block Coefficient: } & 0,65\end{array}$

3. Kapal hydraulic platform ini memenuhi persyaratan stabilitas kapal, trim, dan freeboard.

4. Desain Rencana Garis, Desain Rencana Umum, dan Desain 3D dapat dilihat pada lampiran.

\section{DAFTAR PUSTAKA}

[1] [2]
A. Kusumadya, "Regional Nusantara Batam Peningkatan Jumlah Wisatawan Mancanegara Masuk Ke Indonesia,” Depok, 2016.

M. . Parsons, Parametric Design (Chapter 11). Michigan: University of Michigan, 2001.

S. Guswanda, "Konsep Desain Unlimited Power Cruise Dengan Memanfaatkan Energi Ombak Dan Cahaya Matahari Untuk Wisata Bahari Pada Daerah Coral Reef Triangle (Wakatobi - Raja Ampat)," Surabaya, 2017.

I. M. Organization, International Convention for the Safety of Life at Sea. London: IMO, 1988. 